\title{
The Crisis of the Bureaucratic State and the Failed Attempts to Overcome it in the Russian Public Service
}

\author{
Alexander V. Obolonsky \\ UDK \\ $35.076(470)$ \\ $321.015(470)$ \\ $35.072 .22(470)$ \\ Review scientific paper / pregledni znanstveni rad \\ Received/primljeno: 12. 4.2017. \\ Accepted / prihvaćeno: 22.12. 2017.
}

The article integrates several theoretical and practical issues into the general context of the contemporary crisis of the bureaucratic state and a quest for new patterns of governance. Considering the paradox of the positive influence of social distrust on political development, the dependence between trust and corruption, and recent changes in the public management of several leading countries as a kind of administrative response to new situations in the contemporary world, the author devotes the main part of the article to the case of Russia. Several rounds of unsuccessful efforts to create a genuine public service in post-Soviet Russia are described and the reasons for failure are explored. The common denominator of the author's approach is an appraisal of the current condition of bureaucratic state institutions and personnel as unsuited to contemporary pub-

* Alexander V. Obolonsky, Professor at the National Research University Higher School of Economics, Moscow, Russian Federation (professor na Fakultetu za ekonomiju, Nacionalni istraživački centar, Moskva, Rusija, e-mail: aobolonsky@hse.ru) 
lic expectations and demands, and the vital need to make them much more responsive and cooperative.

Keywords: governance, public service reforms, public trust, Russia

\section{Introduction}

The purpose of this paper is to consider several acute problems of political and administrative theory and practice at a time of a general crisis of the bureaucratic state: the current decline of public trust in executive institutions and persons in power, the paradox of the positive influence of public political distrust on political development, the dependence between trust and corruption, and the attempts of administrative science in several countries to find a new pattern of relationships between state and civil society. Combining these initial prerequisites in a single approach, the author devotes the major part of the paper to the case of Russia; i.e., he provides a detailed description of the several rounds of efforts to create a genuine public service in post-Soviet Russia and analyses the reasons for their dramatic failures and disappointments.

\section{The Issue of the Decline of Public Trust}

\subsection{Phenomenon and Reasons for Decline}

Modern governments face new changes, one of which is most certainly the decline of trust in public institutions, public officials, and politicians. The massive and ever-larger street demonstrations and protests in over a hundred Russian towns and cities in the spring and summer of 2017 were a reaction to corruptive abuses of power, and serve as a remarkable example of both public political awakening and the inability of the authorities to meet the new challenge adequately. The authorities' reaction to these events is a mixture of fear, brutality, and lack of understanding of what is going on. Ordinary people are becoming increasingly convinced that those in power have other priorities than to serve the public and are ready to oppose them in different ways, even at the risk of being arrested. As recently witnessed during the events in the centre of Moscow on Russia Day - a national holiday observed on June 12- and several times previously, during the spring 
months, most of the young people in the crowd overcame their natural physical fear and were psychologically ready to be detained and exposed to administrative arrests. The clumsy efforts of the authorities to both frighten youth by the brutal actions of detachments of special guards and to distract them by different means of entertainment were unsuccessful and counterproductive in some way. This is not exclusively a Russian issue. Similar waves of "occupy" and other protest movements could be observed in many countries in the period 2011-2017, from the USA to Ukraine, and from the Arabic region to Iran and Hong Kong. It may be said that a rather serious alienation of the people from the state is underway.

It is important to note that the leaders of street protests are well-educated and personally successful young people. Because they are better educated and informed, they understand their human and political rights better and see the possible threats clearly. As a result, they treat governments and public services more critically. Public expectations have grown and demands addressed at governments have multiplied, and because these demands are not being fulfilled, the level of dissatisfaction has increased. The inability of governments to effectively manage painful social problems and to meet the challenges of the new age is becoming obvious to the public and causes people to distrust the bureaucratic system as such. Altogether, it is possible to speak about a general crisis of the bureaucratic state model in general, at least in its traditional forms.

The reactions of different governments to this situation range from rhetorical complaints of how "it is difficult to govern in an anti-government era" to real, serious efforts to reform the civil service and other public institutions. Some scholars claim that this is just a part of the story; i.e., the necessary rejectionist step in constructing a new governance paradigm (s. for example Barabashev, 2016).

The events of the last 40 years, especially the horrible atrocities of those in power in totalitarian and authoritarian states in the 20th century have taught the citizens to be suspicious, or at least cautious, of their governments' ambitions and expansion. As a result, the civic "desacralisation" of the state, even in countries with a long-term statist and paternalistic tradition like Russia, has become an empirical fact. It may be considered one of the major intellectual achievements of the second half of the 20th century and may be interpreted as a reincarnation of the liberal concept of the role and place of the state in public life.

In the field of public administration this shift has resulted, in particular, in a move from the state providing public services directly to assuming a 
coordinating and monitoring role in providing public goods. This movement originated against the background of the New Public Management reforms and even acquired the name of "managerial revolution". The USA and the UK were the pioneers and leaders of this process. In the US it was launched in the first half of the 1990s in the form of a program called Reinventing Government. However, the program faced some political obstacles and was only partially realised, bringing about negative effects and disappointment. Another, more successful, example was the almost unprecedented reform of the Civil Service Commission in Britain. The continental European countries took only a few more modest steps in a similar direction (s. Obolonsky, 2011, pp.61-193, Obolonsky, 2014, pp.145-170, etc).

However, most of these steps were just technological half-measures and not capable of providing a satisfactory solution to the problem of public needs. This paper argues that the reason is that once again the reformers began from the obsolete, corporative bureaucratic view, based on the conviction that the administrative system might be reformed successfully just by means of internal technical improvements. That seems to be the wrong idea. An old French proverb says: "don't ask the frogs to drain the swamp where they live". This means, in the context of this topic, that to overcome the deficiencies of bureaucracy by means of creating new administrative bodies contradicts the very logic of genuine reform. ${ }^{1}$

Following this line of reasoning, there is also the question of whether the modern concepts of New Public Management and good governance suit post-communist East European countries. There are opposing views and some answers are negative. They presume that the so-called burden of mentality, the "curse of tradition", or the "cultural code", sometimes referred to as the "Moscow matrix", the "Muscovite system" and so on, is an unchangeable factor and that societies are doomed to obey and bear this burden forever. This position is predicated on the presumption that autocracy is an inherent trait for some societies, which are "genetically" not suitable for democracy. It has had a long history and, unfortunately, is supposedly confirmed by many empirical cases. In recent literature it has been revived, in particular, by the American scholar E. Keenan (1986,

1 This is in line with Laffon $(2005$, pp. 106,142) who remarked: "while the other European countries conduct rather radical public service reforms, France doesn't hurry to join to them, restricting itself by the half-measures and still continues to be one of the last strongholds of centralization and bureaucratism, because the state sector consists of dinosaurs who don't wish to shake the former way of matters". 
p.75). ${ }^{2}$ However, there are also different views, stating that tradition is not the only factor, although it is a very important one. Namely, the struggle against inferior and obsolete traditions and the efforts to overcome them are essential to progress. The history of the 20th century offers many remarkable examples for this.

Certainly, it is not easy for societies like Russia and other parts of the dissolved Soviet Empire. These societies are starting from a lower point compared to more fortunate societies, which means it is more difficult to reach a "new horizon". However, it seems that a successful transformation of the wrong traditional model of governance into a modern one is the only reliable way for all post-Soviet countries to avoid the threat of being transformed into fully-fledged bureaucratic states, bureaucratic forms of reign with all the inevitable consequences: the uncontrollable growth of the size and influence of an irresponsible bureaucracy, its low effectiveness, flourishing corruption, a revival of the nomenclature system, and the like.

\subsection{Dependence of Corruption and Public Trust in Different Societies}

There is a rather popular but seemingly doubtful assumption that corruption in transitional countries is radically different in comparison with corruption in developed ones. First, a high level of corruption in the former is supposedly inevitable. Second, people allegedly think that corruption is an essential and unavoidable part of the so-called "national mentality". Third, it is even thought to be a certain positive and progressive factor at the transitional stage. These points will be briefly considered below.

For the proponents of the first point, the level of corruption and level of trust have a clear negative correlation: less trust equals greater corruption, while greater trust equals less corruption. For example, within the framework of new institutionalism and Public Choice Theory, the negative effect of corruption on economic development is considered in terms of transaction costs, the rent-seeking behaviour of bureaucracy, the prisoner's dilemma, and so on. One of the empirical arguments is that the rise of trust in government by just 1\%, brings about the growth of GDP per capita by as much as $\$ 660$ in five years' time. Francis Fukuyama considered

2 S. also papers presented at the international conference "Rossia 1917-2017. Evropeyskaya modernizatsia ili osobyj put'? - The 17th Leontievskie Chteniy in St-Petersburg in the winter of 2017. 
social distrust to be an additional tax imposed on all national economies (Fukuyama, 1995, p.65). A possible reservation in this context could be that whilst this is correct in general, it does not hold true for all countries: in totalitarian and post-totalitarian states the situation is more ambiguous. A mistrust of bosses and their orders may, in some circumstances, serve as self-defence and save human lives.

The second claim is developed as a result of a so-called "revisionist" approach. Scholars such as S. Lipset (Lipset \& Schneider, 1987), S. Rose-Ackerman (1999), and others did not consider corruption to be pathological or a deviation from the norm, but believed it to be a kind of perverted norm, supposedly inherent in transitional societies as an essential way of exchanging resources in societies where modernisation has been delayed. Some authors like S. Kordonsky, for example, even introduced the special notion of administrative rent to describe corruption as the supposedly appropriate mechanism for the regulation of relationships between state institutions and business (Kordonsky, 2012, 2016).. In other words, this is a kind of institutionalisation, a legitimation of corruptive relationships. Supporters of this approach treat corruption as an inevitable consequence of a specific form of the state-society relationship: not as a principal-agent model but as a patron-client model. Unfortunately, it has acquired some popularity in certain circles.

It would not be difficult to find several relevant empirical examples in favour of this point of view. Unfortunately, in post-socialist states of Eastern Europe both the authorities and public opinion are inclined to treat corruption in a conciliatory way, as an inevitable evil and an appropriate mechanism to facilitate business development. However, to use the widespread existence of something wrong and unlawful as an argument for the legitimation of obviously negative practices like corruption seems incorrect and dangerous. This is a step from the position of analyst to the position of apologist for an existing, but definitely defective, administrative and political order. To continue with similar false logic, any crimes could then be justified, including genocide, deportation, concentration camps, and so on. Therefore, to consider corruption an appropriate and not a criminal form of behaviour sounds like partial justification of everything initiated by the state.

\subsection{Object of Trust as a Critical Point}

To understand the paradox of the positive role of public distrust, the crucial question is: who is the object of trust? For example, trust in a business 
partner is a positive thing. The same can be said of trust in democracy, the rule of law, social justice, some good public institutions, the integrity of officials, and the honesty of most people. But trust in a corrupt state, in crooked bureaucrats, or in a predatory government? Why? The answer depends on the object of the supposed trust or distrust. On the other hand, this paternalistic form of trust correlates closely with the recognition of one's own inability to make any positive differences in the public life of society. In the terminology of K. Popper (1945), it looks like a destructive attitude undermining the chances to create an open society, or a society of open access, in the categories of D. North (North, 1991).

So, the progressive, positive role of distrust when it comes to "bad", or corrupt, politicians and other officials should be emphasised. It is distrust that triggers the making of a difference; in particular, the removal of corrupt individuals from government. For example, it was distrust that made the crucial contribution to the creation of American society. Let us remember who the first waves of immigrants from Europe were composed of. These were people who had ceased to trust their old governments. They had fled their native countries and taken enormous personal risks in an effort to find a place to build a new way of life on the basis of self-government, and to make a new start. Another, more recent, example may be the Maidan phenomenon in Ukraine. Despite all the differences, psychologically there was a similar source of motivation.

In contemporary Russia betrayed trust may be observed. During perestroika, people had made a clear and strong social appeal for democracy, for the dismissal of corrupt officials at all levels, and so on. They believed in new faces with democratic manners and rhetoric. Unfortunately, this trust contained a sizeable dose of naive idealism. It was cynically exploited and betrayed by the newly rich and their administrative "servants". Surely, a gap between high expectations and severe reality and accompanying public disappointment is inevitable, especially in periods of transition. Reality always differs from romantic hopes and beliefs. However, in the Russian case the size of the gap and scale of the disappointment proved to be too large, and the price paid for this was the loss of trust in democratic institutions as such, and in social justice overall - particularly in the possibility of honest governance. A negative consequence to arise from this was the emergence and development of Putin's autocratic state regime and the terrible growth of systemic corruption.

The phenomenon of trust is therefore ambiguous and should be considered differently, depending on its form and object. Unconditional, personalised trust in monarchs, national leaders, presidents, and so on, is an archaic, pa- 
ternalistic form of trust. The very idea of constitutional rule developed from the basis of the philosophy and culture of distrust. The ideology of limited, informed, and controlled trust is a substantial part of democracy. Ironically, this is expressed well in the Russian proverb "Trust, but verify", memorised by US President Reagan during his negotiations with Gorbachev.

Finally, trust between public officials and citizens must be reciprocal. The obligations of all parties to the relationship should be mutual. On the one hand, there are citizens, businesses, or NGOs, while on the other hand there is the state, represented by public officials. Only in this case does trust deserve to be considered a positive factor. Practical forms of trust can be different. It might be informal, based on custom or consensus, like in medieval societies, or it might be formalised in the constitution or other constitutional acts, like in Western countries. In any case, it should be based on a kind of "covenant", or public agreement. The key words in this context are solidarity and voluntary cooperation.

\section{The Case of Russia ${ }^{3}$}

Turning to Russia's attempts to reform its bureaucracy, it should be emphasised that this experience, in general, was unsuccessful and even discouraging. However, it deserves to be studied carefully because it reflects some common traits of post-communist specifics and is part of a more general issue: why is it so difficult to reform a bureaucratic state in transitional countries? The Russian example therefore seems quite interesting from a comparative perspective.

Despite all the diversity of East European countries (a similar heritage, single-party governance, and totalitarian regimes) similar problems arose and have posed common obstacles to conducting reforms. In particular, these are:

a) In all socialist countries middle-ranking bureaucrats were mainly just "cogs" or "driving belts" of the ruling party

b) To all intents and purposes, the merit system did not exist and a degenerate version of patronage in the form of a party-nomenclature system prevailed instead

${ }^{3}$ Several parts of this section represent the author's reflections originally published in a Russian-language textbook (Obolonsky, 2009, pp. 259-298) and English book chapter (Obolonsky, 2009a, pp. 301-316). However, the author finds it reasonable to retell these reflections and develop some of them further in abridged and modernised form. 
c) The public service did not exist either, in its genuine sense, because it is incompatible with autocratic rule.

After the fall of communism, some post-socialist countries made certain efforts to create a genuine public service, with varying results. However, it would be hard to name a completely successful example of public service reform in this part of the world. Moreover, variations of the bureaucratic state emerged in many countries, including Russia. It seems remarkable that even the name of Russian officialdom emphasises the word "state", not "public".

Since 1991 Russia has had a minimum of five attempts at reform, with very modest actual achievements. The essence of all these attempts was a hidden but persistent struggle between two incompatible paradigms, or a competition between two opposing approaches. The first approach champions a kind of pseudo-reform with a minimum number of practical steps towards a true public service and a step backwards in institutionalising and protecting the privileged status of the bureaucratic corporation. The second approach seeks to carry out a real modernisation of the administration in accordance with the demands of the contemporary age and the challenges of truly democratic development.

The first model rests on the traditional idea of the "ruler's service," (gosudareva sluzhba in Russian). Neither during the tsarist period nor the Soviet one had the patrimonial model of administration been oriented towards serving the needs of the people. Instead, it was mostly oriented towards looking after the needs of the ruler ("master", as Stalin was unofficially named), regardless of his formal title. This was the case even when the leader's role was not embodied in one person but in a group, for example, during more recent periods of Soviet history when the Politburo was the collective leader of the country. The second model, which would be a novelty for Russia, would be a civil or public service, (grazhdanskaya or publichnaya sluzbba in Russian), whose first priority it is to serve the needs of the citizens.

\subsection{First Round (1991-1995)}

In spite of the dramatic announcements of early reformers that a new state administration would be created from scratch, Russian post-communist bureaucracy was very much the successor of the Soviet "administrative-command system" both in personal and administrative aspects. As a result, 
the same persons whose entire careers had been spent in the role of the "transmission belts" for Communist Party policies, found themselves in the position of implementing the opposing post-communist politics of liberal reform. This exorbitant personnell continuity, combined with the complete lack of any steps in the direction of lustration became some of the crucial obstacles to successful transition. It marks a crucial difference between transition in Russia and in other post-communist East European countries. Moreover, the intellectual level and the lack of awareness of personal social responsibility for their actions (or inaction) - despite several exceptions - obviously did not match the duties and tasks that needed to be performed.

In a formal sense, the reform process started on November 28, 1991, when President Yeltsin signed a decree that established the Main Department for the Training of State Officials, as part of the Russian Government. The functions of this agency were considerably broader, however, than the name suggests. That was evident in the department's acronym, Roskadry (Russian personnel). However, the main problem - what kind of administration was needed for the new Russia - had not even been seriously formulated then.

Instead, a completely different set of issues proved to be at the top of agenda. Besides the habitual question of who would "call the tune" within the state administration, the main focus centred on the struggle for the control over the prominent and lucrative part of the communist inheritance, the system of higher party schools, at the head of which stood the Academy of Social Sciences of the Central Committee, which for decades had served as a "crucible of personnel" for the higher ranks of the party apparatus (Huskey, 2004). The actors of this struggle were two types of educational institutions - the higher party schools and the newly-emerging departments of public administration at universities and research institutes. Eventually, the "heirs of the party", headed mostly by the same old-style communist bosses, emerged victorious.

This outcome had serious negative consequences because party school personnel held very negative attitudes concerning "the new times". This was not surprising because they had all been carefully selected during Communist Party rule on the basis of their ideological loyalty and the ability to serve as defenders of the policy of totalitarian government. At the beginning of the 1990s these schools were staffed by personnel who held overtly revanchist attitudes towards liberal market institutions and freedom in general.

However, despite their retrograde character, they managed to receive the lion's share of budget allocations for the retraining of state personnel. 
Moreover, the chief successor of the old party's personnel retraining pool, the Russian Academy of State Service (RAGS), became the main consultant to the president in the reorganisation of state service. It is also remarkable that when RAGS looked for external advice, it reached out to representatives of the French administrative tradition, which, despite all its positive features, had been reluctant to embrace the New Public Management movement and other innovations of the time. Russia therefore armed itself with weapons from an obsolete arsenal (Suleiman, 2003, p. 38). As a result, the legislative changes that were made in this period contained little that was substantially new, and in some cases actually restored some archaic constructs from Russia's distant past.

An example of this was the restoration, in 1995, of a rigid grading system within the Law on the Fundamentals of State Service of the Russian Federation. This meant that almost three centuries after its initial introduction, Russia had revived and updated the Table of Ranks. ${ }^{4}$ It is bitter Kafkaesque irony that one of the first actions of the new, supposedly democratic, Russian government, was the restoration of a special corporatist status of bureaucracy, and the elimination of what was one of the few real achievements of the revolutions of 1917. Progressive officials such as Mikhail Speransky, as well as almost all of the Russian monarchs of the 19th century had realised that the potential positives of the Table of Ranks had been exhausted, and only its negative effects were being enforced. Even in Western Europe, where service grades and ranking played a much more modest role than in Russia, they are currently gradually moving towards an inglorious end. The outstanding Russian linguist Y. Lotman (Lotman, 1994) called it "the mystical power of rank" (mistika china). Over a century ago, M. Saltykov-Shchedrin (1988, first publication 1869) remarked bitterly that out of all the achievements of Europe, Russia had borrowed only the division of people according to rank, which by that time Europe had already abandoned.

While Russia was reintroducing an institution whose inadequacy had already been recognised in the 19th century, the real issues remained unresolved. One example was the failure to introduce new blood into the state administration. Until the late 1990s, the continuity of administrative officials inherited from the Soviet era remained at 60-70 per cent, and stood even higher in some agencies (Kryshtanovskaya, 1996, p. 6). Thus funda(1980).

${ }^{4}$ On the role of the status of rank in the history of Russian officialdom, s. Bennett 
mental policy reforms had been implemented by people who had spent their whole careers in an anti-market, administrative-command system. Although Roskadry was closed in 1994, this aspect of policy changed little until 1996. Overall, the general assessment of the first round is negative.

\subsection{Second Round (1997-1998)}

The second round began on a much more promising note. In 1997, President Yeltsin issued a decree that created the Commission on State Reconstruction, later renamed the Commission on Administrative Reform, which was joined by leading academic experts in law and public administration, including the author of this article. One of the commission's primary tasks was the elaboration of a conceptual model for the genuine modernisation of state administration and, for the first time in Russian history, the creation of a genuine public service instead of different modifications to the traditional "ruler service" - a public service that would work for the citizens, the taxpayers, rather than for political bosses. The primary concern was personnel rather than structural issues. We tried to combine Russian specifics with the latest experience of civil service reforms in leading Western countries, especially Anglo-Saxon ones.

The concept was mainly completed by the fall of 1997 and formally enjoyed political support at the highest level. In the spring of 1998, President Yeltsin even included its major points in his annual statement to the Parliament: the competitive hiring procedure; reducing the number of employees and hiring fewer but better paid, better qualified, and honest personnel; a clear, formal statutory differentiation between political appointees and career bureaucrats; the monetisation of privileges; and the protection of qualified officials from administrative pressure and the caprices of their political superiors (Poslanie Federal'nomu Sobraniyu, 1998).

Although the commission enjoyed the patronage of the president, some influential actors within the government and the presidential administration opposed this concept and managed to block any practical steps towards its implementation by hidden bureaucratic combinations. The details are still not available.

So, at first glance, the second round appeared to represent complete victory for the anti-reformist wing of the state bureaucracy. However, the results were not wholly negative. First, it became obvious that the second round had laid a theoretical groundwork for reform and demonstrated 
the absence of adequate alternatives. Second, the reformist ideas clearly formulated in this round entered the consciousness of the country's political-administrative elite to some degree and were developed among university circles and students; i.e., by the next generation of state officials.

\subsection{Third Round (1999-2000)}

The autumn of 1999 brought a new but brief flurry of activity around reform, primarily stimulated by political circumstances. The political agenda was dominated by a struggle for Yeltsin's legacy. In accordance with the age-old Russian tradition of seeking a scapegoat in troubled times, this role was assigned to bureaucrats.

The most successful players at this game grew to be the pro-Putin party, Unity. A think-tank related to Unity, the Centre for Strategic Research, headed by the economist German Gref, prepared a substantial paper about condition of state service and the insistent need to reform it. ${ }^{5}$ Half of those who contributed to the paper were "the people of '97", who provided a continuity of ideas and content. Besides some minor differences and a more detailed description of certain elements of the reform and practical steps towards seeing it through, the document contained some very harsh criticisms of bureaucracy. Reflecting the pre-electoral atmosphere, it argued that state administration in post-communist Russia reproduced some of the worst features of Soviet officialdom, especially its corporatism, or caste-like character. The main focus of the criticism was the huge increase in administrative organisations and personnel, and particularly the enormous network of the federal ministries' annexes in the provinces. In some regions, federal employees outnumbered their regional colleagues by a stunning ratio of ten to one. ${ }^{6}$

On the whole, that document was a more pragmatic version of the program of 1997. Unfortunately, it never produced any practical results. After the elections of 1999 and 2000, interest in the reform dissipated and other issues took its place on the political agenda. As a result, the third round of reform shared the fate of its predecessors.

\footnotetext{
${ }^{5}$ For a discussion of Gref's proposals, see Reforma gosudarstvennogo upravleniya v Rossii (www.parreform.ru/bulletin/), a website maintained by the World Bank.

${ }^{6}$ Chislennost' rabotnikov organov gosudarstvennoy vlasti i mestnogo samoupravleniya po sub'ektam Rossiyskoi Federatsii na konets 2000 goda.
} 


\subsection{Fourth Round (2001-2002)}

However, the pressing need to do something about the growing problems in the Russian administration determined the following, fourth, round. In the fall of 2001 a new reform commission was established. It was composed of high-ranking officials and headed by the Prime Minister, M. Kasyanov. The responsibility for the practical introduction of reform proposals was assigned to several parallel groups operating within the presidential bureaucracy, the Duma, and the Ministry of Economic Development, headed by G. Gref. In contrast with the Yeltsin era, these groups operated in the spirit of Soviet organisations, secretly and outside of public scrutiny, which initially gave rise to suspicions regarding the true political priorities of the supposed reformers.

It seems important to note that "the red line" dividing the supporters and opponents of reform, i.e., the proponents of progressive as opposed to conservative models of change, did not follow strict ministerial or departmental borders. The situation was and still is more complicated and fluid. It would therefore not be appropriate to associate friends or foes of reform with particular administrative or political bodies. This is a specific issue, and a four-level sociological typology of pro-reformers and counter-reformers was eventually established, subdividing them into pragmatic, ideological, and psychological types at each level (Obolonsky, 2009)

\subsection{Fifth Round (2002-2012)}

At first glance, the fifth round had once again started on an encouraging note. The Federal Program for the Reform of State Service, 2003-2005 was published on November 19, 2002. It contained statistical data on the growth of Russian officialdom in the post-communist era, analytical anti-bureaucratic critiques, the main priorities of the reform, a list of the measures that needed to be taken and their detailed schedule with regard to particular executive agencies, the budget for each of the steps, and finally, a list of presidential and government sub-laws and other normative acts needed.

The analysis offered by the Federal Program was critical and almost alarming. In a certain sense, it revived the "spirit of "97", i.e., the second and most advanced round of reform. On the other hand, it reflected a compromise with the advocates of pseudo or "virtual reform" - in particular, the desire to protect the machinery of the state from external and public 
control and scrutiny. However, despite all its inconsistencies, the program as a whole opened up an opportunity for making serious progress in transforming Russia's traditional model of "ruler's service" into civil service.

Nevertheless, once again the declarations of the program did not correspond with the practical steps that followed. A spirit of bureaucratic inertia and hidden resistance prevailed once more. I suspect that the decisive choice between democratic and technocratic approaches to governance, a choice in favour of bureaucratic technocracy and full administrative vertical obedience, was made at the top of the political heap at the time. The Chodorkovsky trial was a major political indicator, and the fate of the draft law "On Civilian State Service" proved to be a part of this choice.

This law was considered crucial by reform proponents, but the exorbitant compromises made between pro- and counter-reformers during the revision stage deprived it of its crucial elements and, to an extent, its essence. For example, the introduction of an equalising scale for military and civilian ranks opened up the way for the mass transition of high-ranking military and security officers to positions in the civilian administration, regardless of their qualification for such jobs. This and other elements of the draft law were the subject of serious criticism during preliminary parliamentary hearings in the spring of 2003. In particular, some deputies noted that the law in its current form would serve corporate interests more than those of the public. But the draft passed through the formal reading without serious discussion or amendments. It was the last session of the Duma before the December 2003 elections, and the deputies were completely focused on their re-election concerns. The final version of the law was adopted on 7 July, $2004^{7}$ by the next Duma, when the single-party dominance of United Russia made any serious revisions to the text impossible. As a result, all the criticism expressed earlier was lost.

By the summer of 2007, this round, which had started with such promise, came to a disgraceful end. The work continued in a formal sense. The president had signed most of decrees set out by the reform program. Their purpose was to improve performance assessment (attestatsiya), create reserve lists of personnel targeted for promotion (kadrovyi rezerv), establish a commission to handle disciplinary and ethical complaints against officials, and introduce competitive hiring.

7 Deputies from the Union of Right Forces must share some responsibility for this. Their criticism of the bill simply meant to score political points instead of taking real and positive steps towards improving the bill, which is the essential duty of responsible lawmakers. 
However, it was difficult to find any substantive changes to the style and nature of how the bureaucracy operated. Instead, we faced an almost explosive growth in the number of bureaucrats, exceeding 1.5 million persons at the time, and the rise of their ambitions as the supposedly "new class" to rule the country.

Even small positive steps looked more like a fulfilment of a formal duty to do at least something in the style of "wiping the slate clean" (ochistit' bumagu), to use an old, cynical, bureaucratic expression, rather than a desire to advance reform. Moreover, in the draft of the next reform program for 2008-2012 even the word "reform" had initially been excluded in favour of the more flexible, but less meaningful and binding term "development". Fortunately, this draft became the subject of serious criticism at a conference held at the Higher School of Economics, and the word "reform" was restored. However, this very fact seems a clear indication that the struggle for true reform of the state bureaucracy had reached its infamous end.

If we return to the boxing metaphor, the end of the fifth round seems a pale imitation of the process in which a fighter has lost their will to compete and is merely awaiting the bell or the signal of the referee. The subject of the reform has been forgotten since then. The following political events and economic crisis made the prospects of reform quite uncertain, if not hopeless, at least in the current circumstances and under current political leadership.

\subsection{The Reasons for the Failure of Reforms}

The particular reasons for the failure of reforms were different at each stage of the transition. In the period 1991-1996, the political situation in Russia was highly unstable and the dangers of the restoration of communist rule, including a violent revenge scenario, were quite real. In addition, the adverse economic situation in the country made any steps directed against the current administrative machinery more risky. It was a time of bitter ideological debate over the future direction in which the country should develop, and the government might have been afraid of creating another enemy inside the system. Therefore, in this period the advancement of the reform process faced mainly political obstacles.

If we consider the 1990s a time of an incomplete anti-communist revolution (which is the dominant approach in liberal circles in Russia), then among the reasons for the absence of a serious transformation in this period was the risk of unleashing yet another reform in such a fragile political environment and on such a weak state. 
But this fear of some decision makers was exaggerated and unreasonable. At that time, the negative feelings of citizens towards bureaucratic nomenclature and the communist legacy in general were still strong enough, and the leadership might have received a popular mandate for public service reform without a problem. Indeed, it seems that to have mobilised public support for anti-bureaucratic actions would have been easier than for anything else. And bureaucracy at that time was disoriented and weaken because it was loosing its habitual identity. In such disintegrated condition it hardly was capable for any serious resistance to possible reform.

The aversion to political risk was not the only complicating factor. Another reason was an underestimation of the critical importance of this kind of reform for general success. Russia's leaders of the period did not consider the transformation of the civil service to be an issue of primary significance.

Although Boris Yeltsin and his team made some efforts to reject the Soviet and communist legacy after the putsch of August 1991, many people in the nomenclature retained their positions and used any available instrument to resist the so-called "de-communisation". As a result, the new political order inherited almost the same executive apparatus. It is not surprising that, after they had recovered from the initial scare at the end of the 1980s and a few subsequent years, the old nomenclature, at first cautiously but then more aggressively, began to carry out a "quiet revanche", blocking or undermining whenever possible the reformist policies adopted by the political leadership. ${ }^{8}$ The former nomenclature even managed to expand their status by means of "transforming power into property."

Russia is not unique in this respect. Practically all post-communist countries faced a certain degree of public disappointment when high expectations of quick and positive results of changes had not been satisfied. However, despite all these difficulties, the 1990s brought a lot of progressive changes and actually saved the country from a catastrophic "Zimbabwe style" collapse. Russian citizens have reasons to feel proud of the final decade of the 20th century, as opposed to what followed - the Putin era. Along with a certain amount of progress, some new barriers to reform have emerged during Putin's presidency. First, it was the absence of open-

8 The opponents of reform within the bureaucracy cooperated frequently, though mostly covertly, in resisting reform. Their resistance included criminal and semi-criminal elements, who had definitely no interest in achieving a more professional, transparent, and honest officialdom.

9 This phrase originates from Egor Gaidar. 
ness, or glasnost', regarding all the reform plans and processes. One of the most serious obstacles to conducting reforms is a closed, semi-secret manner of operating. Because bureaucratic reform presumes a fundamental change in the relationship between state and society, it also presumes the support and approval of the citizens. However, this is not possible without public knowledge and understanding of the proposed changes. The intentions and plans of the reformers must be clearly explained to the citizens, who might then be able to make their own suggestions by way of feedback. If citizens feel this kind of partnership with the reformers and trust them, they could offer some fresh ideas and provide the necessary political counterweight to the anti-reformist forces within the bureaucracy. Moreover, a civil society mobilising around reform will force the bureaucracy to be more accountable and transparent before the public. Particularly, among the many groups in society that have an incentive to support reforms, there are small and medium-sized businesses, who have suffered the abuse of corrupt officials. The inability, or unwillingness, of politicians to mobilise society around reform projects seems to at least partly explain not only the failure of their reform projects, but also the growing public alienation from the political process in general.

I believe there is no reason to fear public incompetence or destructive negativism. In fact, public discussion of reform projects is capable of enriching their positive content and making allies out of citizens. It is also better to get the inevitable, and possibly harsh, public criticism before a law is adopted, while there is still a chance to revise it, rather than to try and convince people of the value of the reform after the fact. As the historian V.O. Kluchevsky noted long ago, a perpetual obstacle in the way of reforms in Russia is "the deep-seated indifference and distrust with which people meet any new appeal coming from the government because they know from experience that nothing good may come of it but new burdens and incomprehensible directives" (Kluchevsky, 1958, p. 87).

Whether in Russia, in the United States or elsewhere, the experience of both successful and unsuccessful attempts to reform bureaucracy illustrates that it is vital for success to acquire allies both within officialdom itself and within society. Officialdom is, after all, heterogeneous, and also harbours proponents of progressive changes. Yes, it would be naive to assume that even the most forward-looking officials are able to elaborate comprehensive programs for changes that might be comparable in value with programs prepared by groups of experts, who have the time and knowledge to do so. However, what is needed from state officials is something different: those who recognise the necessity of reform and agree 
with the general course it should take, could provide active support. I can testify from personal experience of extensive contacts with Russian officials that there are significant numbers of potentially reformist-minded people at different levels of government, and many can become effective allies, and even protagonists, of reform. Besides, this might improve the negative perception of bureaucrats in the public mind to a certain degree. To achieve a breakthrough, political leadership must promote an open dialogue on all acute issues of concern to state and society, and stop setting one against the other. The fear of "colour revolutions", which may unfortunately be observed in the mood and actions of our "political elite", is a dangerous political pathology, on the brink of insanity. Only positive and clear political will in combination with public support and administrative consistency can make a success of the reformist movements.

\section{A Few Concluding Remarks from the Russian "Shore"}

The huge growth in the size and influence of a patrimonial, highly corrupt, self-sufficient, and irresponsible bureaucracy is a particular consequence of not conducting substantial personnel changes in the state apparatus and the absence of vetting it in order to purge it of former high-ranking Soviet "bureaucrats" and KGB officers.

a) The most malignant foes of further reforms are not the people who failed during the first stages of changes but the "early-winners"; i.e., those who managed to acquire gains in the "Klondike times" of the 90s and are eager to save their current privileged positions.

b) The so-called "administrative resource" is the worst and most dangerous bureaucratic mechanism for abuses of power; it can only be successfully fought against under conditions of public control and a truly independent judicial system.

The state itself is a major violator of the law in contemporary Russia. Therefore, a certain mistrust of the authorities, contrary to customary views, holds substantial cultural and human potential for conducting modernisation policies successfully.

The general conclusion is that the current crisis cannot be successfully resolved within the framework of any administrative paradigm, by means of purely technological and/or social engineering improvements. The sit- 
uation needs to be revisited in a broader political and cultural context. The new age demands new approaches to the principles and mechanisms of governance. However, most officials and experts still prefer to rely on old concepts and techniques inherited from the previous political era. A bureaucracy is by definition a rather inertial construct. This trait has had more positive than negative consequences for centuries, but the current situation is radically different in many respects. Old approaches do not work effectively and we are dramatically entering a new world with many challenges, uncertainties, dangers, and opportunities. And unless bureaucracy is capable of finding sufficient wisdom and willpower to exact radical change (to meet new needs and aspirations, intersect with civil society at some points, and the like), many collisions and conflicts, some of them radical, may be expected under the pressure of advancing citizenry and street protests. Russia seems to be one of the most vulnerable points on the map of Eastern Europe in this respect.

\section{References}

Barabashev, A. (2016). Krisis gosudarstvennogo upravleniya i ego vliyanie na osnovnye administrativnye paradigmy gosugarstva i byurokratii [Crisis of state governance and its influence on basic administrative paradigms of state and bureaucracy]. Public Administration Issues, 3, 163-194.

Bennett, H. A. (1980). Chiny, ordena, and officialdom. In W. McKenzie Pintner \& D. K. Rowney (Eds.), Russian officialdom: The bureaucratization of Russian society from the seventeenth to the twentieth century (pp. 162-189). Chapel Hill, USA: University of North Carolina Press.

Fukuyama, F. (1996). Trust: The social virtues and the creation of prosperity. New York, USA: Free Press Paperback Edition.

Federal Program for the Reform of State Service, 2003-2005. Sobranie xakonodatel'stva RF, 25.11.200. N 47, st. 4664.

Huskey, E. (2004). The higher party schools to civil service academies: The marketization of bureaucratic training in Russia. Slavic Review, 63(2), 325-348.

Keenan, E. (1986). Muscovite political folkways. Russian Review, 45(2), 115-181.

Kluchevsky, V.O. (1958). Kurs russkoy istorii v 8 tomakh [Course of Russian history in 8 vol.]. Volume 8. Moscow, Russia: Izdatelstvo sotsialno-ekonomicheskoy literatury.

Lotman, Y. M. (1994). Besedy o russkoy kul'ture [Conversations on Russian culture]. Saint Petersburg, Russia: Iskusstvo.

Kordonsky, S.G. (2016). Socio-economic foundations of the Russian post-Soviet regime: The resource-based economy and estate-based social structure of contemporary Russia. Stuttgart, Germany: ibidem Press. 
Kordonsky, S.G. (2012). Norma otkata [The norm of kickback]. Otechestvennye zapiski, 2, 77-80.

Kryshtanovskaya, O.V. (1996 January 10). Finansovaya oligarkhiya Rossii [Financial oligarchy of Russia]. Izvestiia, p. 7.

Laffont, J.-J. (2005). Etapes vers un etat moderne: Une analyse économique [Stages on the way to a modern state: An economic analysis]. Moscow, Russia: Ambassade De France (in Russian).

Lipset, S.M., \& Schenier, W. (1987). The confidence gap: Business, labor, and government in the public mind. Baltimore, MD: Johns Hopkins University Press.

North D.C. (1991). Institutions, institutional change and economic performance. Cambridge, United Kingdom: Cambridge University Press.

Obolonsky, A.V. (2009). Gosudarstvennaya slyszbba: Kompleksny podkhod. [Civil service: A complex approach]. Moscow, Russia: Delo.

Obolonsky, A. V. (2009a). Why is it so difficult to reform Russian officialdom?. In: D. Rowney, \& E. Huskey (Eds.) Russian Bureaucracy and the State: Officialdom From Alexander III to Vladimir Putin (pp.301-316). Basingstoke, UK: Palgrave Macmillan.

Obolonsky, A. (2011). Krisis burokraticheskogo gosudarstva: Reformy gosudarstvennoy sluzbby: Mezhdunarodny opyt $i$ rossiskie realii [The Crisis of the bureaucratic state: Civil service reform: International experience and Russian reality]. Moscow, Russia: Fond "Liberalnaya Missiya".

Obolonsky, A. (2014). Krisis administrativno-burokraticheskogo gosudarstva i poiski vyhoda: opyt USA (evolyutsia teorii i praktiki upravlemkiya v poslednie desytiletiya) [The effectiveness of the crisis of the bureaucratic state and a search for way out: USA's experience (The Evolution of Theory and Practice of PA During the Last Decades)]. Public Administration Issue, 2, 145-165.

Popper K.R. (1945). The open society and its enemies. Abingdon, United Kingdom: Routledge.

Poslanie Federal'nomu Sobraniyu for 1998 (1998). Poslaniye Prezidenta RF B.N. Yel'tsina Federal'nomu Sobraniyu ot 6 marta 1997 g."Poryadok vo vlasti poryadok v strane" $(\mathrm{O}$ polozhenii v strane i osnovnykh napravleniyakh politiki Rossiyskoy Federatsii [Message of the Russian President Boris N. Yeltsin to the Federal Assembly of March 6, 1997 "Order in power - order in the country" (On the situation in the country and the main directions of the policy of the Russian Federation], Retrieved from: http://www.docipedia.ru/document/5163988.

Rose-Ackerman, S. (1999). Corruption and government. Cambridge, United Kingdom: Cambridge University Press

Saltykov-Shchedrin (1998). Skazki. Sobranie socchineniy $v 8$ tonakb [Collected woks in 8 volumes]. Moscow, Russia: Pravda.

Suleiman, E. (2003). Dismantling democratic states. Princeton, NJ: Princeton University Press. 


\section{THE CRISIS OF THE BUREAUCRATIC STATE \\ AND THE FAILED ATTEMPTS TO OVERCOME IT IN THE RUSSIAN PUBLIC SERVICE}

\section{Summary}

The paper integrates several theoretical and practical issues into the general context of the contemporary crisis of the bureaucratic state and a quest for new patterns of governance. Several subjects are considered: various aspects of the decline of public trust in government, including the civic "desacralisation" of the state, the paradox of the positive influence of social distrust on political development, and the dependence between trust and corruption. Noting the serious efforts undertaken in several leading countries during the last 30 years in order to overcome this crisis, and the recent changes in their public management as a kind of administrative response to the situation, the author concludes that most of these steps, because of their purely technological character, did not pose a real alternative and could not solve the problems in accordance with current public needs and expectations. The main part of the article is devoted to the case of Russia - a description and analysis of five rounds of unsuccessful efforts to create a genuine public service in post-Soviet Russia and an analysis of the reasons for failure. Despite some partial improvements, the general results are judged to be a dramatic failure, causing the appearance of fully-fledged bureaucratic state with all the inevitable negative consequences. The most malignant foes of reforms in Russia are not the people who failed during the first stages of changes but the "early-winners"; i.e., those who managed to acquire gains in the 90s and have tried to save their current privileged positions by any means, including the so-called "administrative resource" and other abuses of power. The Russian experience also seems quite interesting compared with all other post-socialist East European countries. The common denominator of the author's approach is an appraisal of the current condition of bureaucratic state institutions and personnel as unsuited to contemporary public expectations and demands, and a vital need to make them much more responsive and cooperative. Namely, it seems obvious that a new world is opening up with respect to the place and role of executive public officials.

Keywords: governance, public service reforms, public trust, Russia. 


\title{
KRIZA BIROKRATSKE DRŽAVE I NEUSPJEŠNI POKUŠAJI RJEŠAVANJA KRIZE U RUSKOJ JAVNOJ SLUŽBI
}

\begin{abstract}
Sažetak
U radu se isprepleće nekoliko teorijskib $i$ praktičnib pitanja, a sve unutar širega konteksta suvremene krize birokratske države i potrage za novim obrascima upravljanja. Razmatra se nekoliko tema: različiti aspekti pada povjerenja javnosti u državu, uključujući građansku »desakralizaciju" države, paradoks pozitivnog utjecaja nepovjerenja društva na politički razvoj, te povezanost povjerenja i korupcije. Mnoge su države tijekom posljednjib 30 godina poduzele ozbiljne napore kako bi riješile krizu i na nedavne se promjene u njibovu javnom upravljanju može gledati kao na svojevrstan administrativni odgovor. No autor ipak zaključuje da većina tib promjena, sobzirom na to da su bile isključivo tehničke prirode, nije predstavljala stvarnu alternativu te one nisu mogle riješiti probleme u skladu s očekivanjima i potrebama suvremenog društva. Glavnina je rada posvećena slučaju Rusije. Opisuje se i analizira pet krugova neuspješnih pokušaja da se nakon raspada Sovjetskoga Saveza u Rusiju uvede javna služba u pravom smislu riječi. Usprkos djelomičnom napretku, pokušaji su rezultirali značajnim neuspjehom te je došlo do razvoja birokratske države i neizbježni popratnih posljedica. Najveći neprijatelji reformi u Rusiji nisu oni koji su se susreli s neuspjebom u prvim fazama promjene, već su to "rani pobjednici" - oni koji su 1990-ib stekli povlastice $i$ potom ib nastojali zadržati na sve moguće načine, pa tako i zlouporabom moći. Ruska su iskustva također vrlo zanimljiva u usporedbi s iskustvima ostalih postsocijalističkih istočnoeuropskih zemalja. Autor ocjenjuje da sadašnje stanje birokratskib državnib institucija i njibovih zaposlenika ni u jednoj zemlji nije u skladu sa suvremenim očekivanjima $i$ zabtjevima javnosti te drži da je potrebno znatno povećati razinu njibove odazivnosti i suradnje. Očito je da se uloga javnih službenika mijenja iz temelja.

Ključne riječi: upravljanje, reforme javnih službi, povjerenje javnosti, Rusija
\end{abstract}


